УДК 342.52

DOI https: / / doi.org/10.32837 / yuv.v0i5.2001

Г. Берченко,

кандидат юридичних наук, доцент,

доцент кафедри конституційного права України

Національного юридичного університету імені Ярослава Мудрого

\title{
ПРЕДМЕТ ЗАКОНОДАВЧОГО РЕГУЛЮВАННЯ I ЙОГО МЕЖІ В КОНТЕКСТІ НОРМАТИВНОГО РЕГУЛЮВАННЯ ЦІН (ТАРИФІВ)
}

\begin{abstract}
Конституційний Суд України (далі - КСУ) час від часу стикається із проблемою компетенції законодавця, предметом законодавчого регулювання, його межами, адже саме порушення таких меж може наводитися як аргумент неконституційності положень закону. Останнім часом відповідна проблема актуалізувалася у зв'язку з конституційним поданням 47 народних депутатів України щодо відповідності Конституції України (конституційності) положень абз. 1-4 ч. 2, ч. ч. 3, 6-9, 12-22, 26, 28-33 ст. 9-1, положень ст. 9-2 Закону України «Про альтернативні джерела» та положень ч. ч. 2,4 , п. 3 ч. 9 ст. 65 Закону України «Про ринок електричної енергії.

Метою статті є з'ясування меж законодавчого регулювання в контексті нормативного регулювання цін (тарифів). Завданнями статті є: з'ясувати зміст повноваження парламенту щодо визначення засад внутрішньої і зовнішньої політики; розкрити питання щодо (не)вичерпності предмета законодавчого регулювання ст. 92 Конституції України; з'ясувати юридичні позиції КСУ в частині законодавчого регулювання цін (тарифів).

Варто погодитись із тим, що під час аналізу обсягу відносин, що регулюються тільки законами України, виникає проблема, пов'язана з тим, чи є це коло питань вичерпним. Відповідь на дане запитання може бути однозначна - не є. Законом можуть
\end{abstract}

регулюватися і відносини, що виходять за межі ст. 92 Конституції Украіни $[1$, с. 99].

Навіть більше, відповідно до позиції КСУ в рішенні від 2 березня 1999 р. № 2-рп/99, законами України можуть регулюватися також інші питання, вирішення яких відповідно до Конституції України не належить до повноважень інших органів державної влади або органів місцевого самоврядування. Це випливає із ч. 2 ст. 85 Конституції України, яка встановлює, що Верховна Рада України здійснює повноваження, які відповідно до Конституції України віднесені до ї̈ відання. I це зрозуміло, оскільки в п. 1 ч. 1 ст. 85 не йдеться про те, що відповідні закони можуть бути ухвалені виключно з тих питань, які перелічені у ст. 92 Конституції України.

3 усіх конституцій демократичних держав тільки чинна нині французька Конституція 1958 р. забороняє парламенту видавати закони з питань, що не наведені у ст. 34, що вичерпним чином визначила законодавчу компетенцію парламенту. Водночас навіть серед особливо зазначених парламентських законодавчих сфер, що стосуються передусім фундаментальних прав, є такі, стосовно яких парламент може визначати лише основні принципи [2, с. 158].

Проте тут потрібне застереження. Як зазначає Ж.-П. Жакке, Конституція Франціі 1958 р. ввела розмежування 
між сферами, у яких закон встановлює правила, і сферами, у яких він визначає основні принципи. Однак Конституційна Рада значною мірою пом'якшила відмінність між цими сфрерами компетенції (рішення від 17 листопада 1959 р.). Конституційна Рада йде набагато далі у своїй практиці щодо визначення сфери закону, посилаючись не лише на ст. $34 \mathrm{Koн}-$ ституції Франції, а й на Декларацію прав людини і громадянина 1789 р., «підрізає» таким чином нововведення Конституціï 1958 р. Урешті-решт, Конституційна Рада у своєму рішенні від 30 липня 1982 р. визначила, що закон, який включає повноваження, що належать до регламентарної сфери, не $€$ неконституційним за своєю підставою. Отже, якщо парламентська більшість ухвалює той чи інший акт відповідно до процедури, то він стає законом незалежно від сфери, яку він регулює, і неможливо на підставі ст. 61 Конституції оголосити його неконституційним на тій підставі, що він втрутився у сферу регламентарної влади. За цих умов нелегко окреслити матеріальну сферу закону [3, с. 332].

Зазвичай законодавча компетенція парламентів невизначена, тобто парламент може видавати закони практично з будь-якого питання. Це випливає із суті законодавчої функції, покладеної на парламент Конституцією. Природно, якщо питання якось урегульоване в Конституціі, закон парламенту повинен їй відповідати [4, с. 36-37].

У класичних парламентських системах первинна правотворчість $€$ прерогативою парламенту. Зазвичай конституції обмежуються констатацією того, що законотворення $€$ правом парламенту; крім того, у тексті здебільшого містяться вказівки на те, що закони поширюються на всі державні органи і всіх громадян. Доручення видання законів виборному (народно-представницькому) органу має основоположне зна- чення $з$ погляду демократії, оскільки воно означає, що громадяни, нехай навіть непрямо, самі створюють для себе закон. 3 погляду конституційності законодавчого процесу дійсна, фактична правотворча здатність парламенту має (повинна мати) принципове значення [2, с. 158-159].

Зрозуміло, і тоді, коли законодавець ухвалює рішення в «позаконституційній» сфері, він зобов'язаний керуватися загальними принципами конституційного ладу і права, зокрема принципом поділу влади. Це означає, що форму закону не можна використовувати для вирішення питань, які за своєю природою становлять предмет виконавчої або судової діяльності. Інакше кажучи, парламент, коли виконує свою конституційну функцію, повинен встановлювати правові норми, а не вирішувати конкретні справи, якщо на те немає прямого конституційного уповноваження [4, c. 37].

На жаль, визначаючись із відповідною компетенцією законодавця, ми одразу стикаємося 3 неоднозначністю (а можливо, навіть і не зовсім вдалим формулюванням), коли в Конституції України окремо вказується повноваження парламенту ухвалювати закони (п. 1 ч. 1 ст. 85) і визначати засади внутрішньої і зовнішньої політики (п. 5 ч. 1 ст. 85).

Природно виникає закономірне питання щодо співвідношення повноваження щодо ухвалення законів i визначення засад внутрішньої і зовнішньої політики. Адже визначення засад внутрішньої і зовнішньої політики також, логічно, має відбуватися у формі закону. Проте не зовсім чітко зрозумілими є ті випадки, коли відбувається визначення таких засад, а коли такі засади вже не визначаються і починається просте законодавче регулювання (не пов'язане із засадами внутрішньої і зовнішньої політики). 3 одного боку, засади з погляду етимологічного тлумачення пов'язані із принципами, проте 
будь-який закон важко уявити без класичних приписів або інших некласичних правових приписів (цілі, дефініції, колізійні норми тощо). Отже, навряд чи засади внутрішньої і зовнішньої політики - це суто норми-принципи.

Варто погодитись і 3 тим, що зміст поняття «державна політика» не визначений у чинному законодавстві [5, с. 81]. По суті, єдиним визначенням державної політики, є визначення, яке свого часу сформулював КСУ в рішенні від 2 березня 1999 р. № 2-рп/99.

Справді, провести межу, де парламент реалізує повноваження щодо ухвалення законів, а де повноваження щодо визначення засад внутрішньої і зовнішньої політики, непросто. Причому в повноваженні ухвалювати закони парламент не обмежений суто засадами в розумінні норм-принципів, і це очевидно.

Якими аргументами керувався конституцієдавець, коли закріплював ці обидва повноваження у ст. $85 \mathrm{Koн-}$ ституції України окремо (п. п. 1 і 5), нині сказати важко. Можливе припущення, що він був натхненний французькою моделлю, тобто ідеєю наділення законодавця правом нормативного регулювання окремих сфер лише щодо основ. Проте самі сфери виписані занадто широко «внутрішня і зовнішня політика», що робить це припущення непереконливим. За таких умов будь-яка законодавча регламентація - це лише основи, оскільки все, по суті, так чи інакше $€$ внутрішньою або зовнішньою політикою. Крім того, наведене припущення не підкріплено окремим регламентарним повноваженням уряду (як це зроблено у ст. 37 Конституціï Франціï). Та й сама французька модель, як зазначалося, зазнала суттєвого коригування завдяки практиці Конституційної Ради з погляду розширення предмета законодавчого регулювання.

Для відповідного вирішення теоретико-правової проблеми з погляду доктрини можна запропонувати вузьке тлумачення механізму реалізації повноваження щодо визначення засад внутрішньої і зовнішньої політики. Нагадаємо, що 1 липня 2010 р. Верховна Рада України ухвалила Закон «Про засади внутрішньої і зовнішньої політики» № 2411-VI. Отже, можна припустити, що визначення засад внутрішньої і зовнішньої політики реалізоване шляхом ухвалення спеціального закону, інші ж закони, ухвалені Верховною Радою України, охоплюються компетенцією парламенту щодо ухвалення законів (п. 1 ч. 1 ст. 85). Отже, на часі формулювання актуального погляду КСУ на таке повноваження парламенту, як визначення засад внутрішньої і зовнішньої політики, з урахуванням усіх названих дискусійних питань і проблемних моментів.

Особливої актуальності відповідне питання набуває у зв' язку із проблематикою цін і тарифів. Узагалі питання про матеріальне розмежування компетенції законодавчої й урядової влади є основною проблемою конституційного права [6, с. 79]. У процесі розвитку ідеї щодо порушення принципу поділу влади і виходу за межі свої повноважень із боку парламенту ми маємо окреслити цю межу.

Регламентарні повноваження, тобто повноваження щодо нормативного регулювання урядів у парламентських країнах, є винятком. Як стверджує Дж. Сарторі, парламентським урядам надано право на видання правових актів, однак їх «управління за допомогою законодавчої діяльності» є правом у виняткових випадках, воно повинно бути виправдано терміновістю і підпорядковуватися суворим правилам [7, с. 156]. Ще Венеціанська комісія зазначала, що повноваження Кабінету Міністрів видавати постанови і розпорядження, що є обов'язковими до виконання, мають підлягати певним чітким обмеженням: їння обов'язкова сила має поширюватися лише на виконавчі органи. Якщо ж 
вона виходить за ці межі, наприклад, коли стосується прав і обов'язків приватних осіб, то для цього вимагається санкціонування законом, що визначає основний зміст та сферу дії таких розпоряджень чи постанов. Інакше нормативі повноваження законодавчого органу можуть бути обійдені або підірвані [8, с. 258].

Відповідно до п. 1 ст. $116 \mathrm{KoH}^{-}$ ституції України, Кабінет Міністрів України забезпечує державний суверенітет і економічну самостійність України, здійснення внутрішньої і зовнішньої політики держави, виконання Конституції і законів України, актів Президента України. Як зазначає Д.Д. Задихайло, аналіз цього пункту ст. 116 Конституції України дозволяє зробити висновок, що в одному пункті уживаються аж три самостійні функції Кабінету Міністрів України, одна 3 яких $є$ головним призначенням Уряду України - здійснювати внутрішню і зовнішню політику держави, адже реалізація політики держави є основною формою діяльності Уряду України. Отже, наведене положення п. 1 ст. 116 Основного закону має бути текстуально, системно та змістовно ув'язаним із положенням п. 3 ст. 116 Конституції України [9, с. 72].

Якщо звернутися до п. 3 ст. $106 \mathrm{Koн-}$ ституції України щодо повноважень Кабінету Міністрів України, ми побачимо там забезпечення проведення фінансової, цінової, інвестиційної та податкової політики. Водночас постає питання - чи має парламент у цих сферах, визначених п. 3 ст. 106 (у всіх чотирьох сферах або лише сфері цін), обмежуватися лише принципами (засадами, началами)? Щодо цін, то в рішенні від 2 березня 1999 р. № 2-рп/99 КСУ визначив: «Забезпечення проведення цінової політики Кабінетом Міністрів України означає реалізацію ним визначених названим Законом України основних начал встановлення $i$ застосування цін і тарифів, що логічно включае регулювання (виділення моє $-Г$.Б.) цін (тарифів), а також контроль за нимu».

Що ж мається на увазі під «регулюванням» - нормативне чи індивідуальне (правозастосовне)? Розуміння регулювання як нормативного, по суті, цілком виводить у неконституційне поле будь-яке нормативне законодавче регулювання цін, окрім принципів (засад, начал). Проте подальша практика КСУ 2004 р. щодо сфери цін і тарифів показала інше. Тому тут, на мій погляд, ідеться про правозастосовне (індивідуальне) регулювання.

Якщо ж взяти інші сфери фінанси, інвестиції і податки, згадані в п. 3 ст. 106 Конституції України, то ми побачимо широке нормативне законодавче регулювання в цих сферах. «Проблема» цін і тарифів лише в тому, що їх прямо не поіменовано у ст. 92 Конституції України як предмет виключного законодавчого регулювання (встановлення). Водночас, як ми вже з'ясували, законодавець має право видавати закони й в інших сферах, не визначених у ст. 92 (і це позиція КСУ). Ключове - щоб вирішення цих питань не належало до повноважень інших органів державної влади або органів місцевого самоврядування. А такі питання до їхніх (інших органів державної влади або органів місцевого самоврядування) повноважень, згідно з Конституцією, не належать.

Визначення межею законодавця в цьому плані п. 3 ст. 106 Конституції України в такому разі для цін (тарифів) не є адекватним. Як можна здійснювати проведення цінової політики i не базуватися на законодавчому регулюванні? I лише одних засад (принципи, або начала) у такому разі явно недостатньо. Інакше конституцієдавець би прямо надав уряду повноваження щодо ухвалення регламентарних актів окремо в ціновій сфері, якби він бажав цілком вивести цю сферу із законодавчого регулювання, 
i залишив для законодавця простір лише у сфері засад (принципи, начала).

До того ж поіменування чотирьох сфер у п. 3 ст. 106 Конституціï України (ціни, фінанси, інвестиціï і податки) означає єдиний підхід щодо них. Навряд чи логічно вбачати цінову сферу в цьому переліку як якусь особливу, що має особливий статус з погляду їі нормативного регулювання, таку, що має базуватися на підзаконній регламентації, водночас інші сфери мають базуватися на регламентації законодавчій.

Тобто підкреслимо, ми маємо розуміти «регулювання», про яке пише КСУ в рішенні від 2 березня 1999 р. № 2-рп / 99, у яке неправомірно свого часу втрутилася Верховна Рада України забороною підвищувати тарифи, як індивідуальне регулювання, тобто правозастосовне. Термін «індивідуальне правове регулювання» активно вживається в теорії права в контексті теорії правового регулювання або механізму правового регулювання. Узагалі ж лише як виняток уряд має право здійснювати нормативне регулювання, але лише в межах компетенції, визначеної Конституцією i законами. Водночас будь-яке повноваження Кабінету Міністрів України або іншого органу виконавчої влади не може визначатися законом усупереч конституційним приписам (рішення КСУ від 13 червня 2019 р. № 5-р/2019). Саме таке тлумачення узгоджується із ч. 2 ст. 19 Конституції України, а також принципом верховенства права (ст. 8 Конституції України). Інакше ми визнаємо невластиву виконавчій владі квазізаконодавчу компетенцію щодо ухвалення регламентарних актів у сфері цін. Навряд чи конституцієдавець закладав саме таку модель поділу влади.

Рішення КСУ від 2 березня 1999 р. № 2-рп/99 було зумовлене тим, що законодавець втрутився саме в індивідуальне регулювання, встановив тимчасову заборону на підвищення цін і тарифів на житлово-комунальні послуги та послуги громадського транспорту, що надаються громадянам України. 3 рішення КСУ випливає, що законодавець не може заборонити Кабінету Міністрів України реалізовувати його ж конституційну компетенцію у сфері правозастосування і перебирати іï на себе, що і відбулося на той час. На той момент сталося, по суті, порушення Конституції ординарним законом. Проте з рішення КСУ від 2 березня 1999 р. № 2-рп/99 не має випливати, що питання тарифів узагалі має бути вилучене з нормативної компетенції парламенту або ж обмежуватися лише засадами (начала, принципи). Саме в цьому ключі, на мій погляд, і варто інтерпретувати відповідне рішення КСУ.

Щодо рішення КСУ від 10 лютого 2000 р. № 2-рп/2000, то воно стосувалося аналогічної ситуації - знову були відтворені положення, визнані рішенням Конституційного Суду України неконституційними. Водночас КСУ так само навів ті самі аргументи і ту ж логіку, що і в попередньому рішенні.

Практика КСУ 2004 р. також спростовує ідею виключно «засад» (принципи, начала) у регулюванні цін і тарифів, зокрема йдеться про п. 7 мотивувальної частини рішення КСУ від 16 березня 2004 р. № 6-рп/2004 (справа про друковані періодичні видання). Із цього рішення випливає, що Верховна Рада України вільна у визначенні політики ціноутворення, встановивши граничний рівень тарифу на оформлення передплати та доставку передплатникам друкованих періодичних видань, що є складовою частиною засад внутрішньої економічної і соціальної політики. Крім того, КСУ визнав індивідуальний правозастосовний акт уряду (постанову) реалізацією повноваження щодо безпосереднього регулювання (встановлення) цін, що підтверджує ідею про те, що проведення цінової політики - це правозастосування на під- 
ставі закону. А от в абз. 4 п. 6 мотивувальної частини КСУ послався на ст. 92 Конституції України, тобто КСУ здійснив подвійну прив'язку, знайшовши компетенцію парламенту щодо тарифів як у п. 5 ст. 85, так і у ст. 92 Конституції України.

Ідея цього рішення КСУ в тому, що парламент має право ухвалювати закони у сфері тарифів, встановлювати законодавчі межі діяльності Уряду з реалізації відповідної політики. Причому такі закони за своїм предметом не $є$ лише формальними «засадами» (принципи), а можуть мати іншу, ширшу сутність і обсяг, бути класичними нормами права. Водночас Уряд здійснює правозастосування, у межах закону реалізовує політику щодо цін.

В іншому, пізнішому, рішенні КСУ був більш стриманий в аргументаціï. В абз. 1, 3 п. 3 мотивувальної частини рішення від 15 квітня 2004 р. № 10-рп/2004 (справа про визначення мінімальної ціни на цукор) КСУ визнав компетенцію парламенту нормативно врегулювати право Кабінету Міністрів України на встановлення мінімальних цін на цукор i цукрові буряки як елемент визначення засад внутрішньої політики в економічній сфері. На думку КСУ, повноваження парламенту випливають як із п. 5 ст. 85 Конституції України, так і $з$ п. 8 ч. 1 ст. 92 Конституції України. КСУ визнав положення щодо визначення мінімальної ціни на цукор конституційними. Сам зміст відповідних положень не вписується у просте формальне розуміння засад і $€$ «компетенційним», тобто законодавець надав відповідні положення Уряду встановлювати мінімальні ціни на цукор.

Отже, можна дійти таких висновків:

1. Уряд має право здійснювати саме індивідуальне правове регулювання у сфері тарифів, відповідний термін активно використовується в теорії права в контексті теорії правового регулювання або механізму правового регулювання і означає здійснення правозастосування.

2. Поіменування чотирьох сфер у п. 3 ст. 106 Конституції України (ціни, фінанси, інвестиції і податки) означає єдиний підхід щодо них. Навряд чи логічно вбачати цінову сферу в цьому переліку як якусь особливу, що має особливий статус з погляду ii нормативного регулювання, таку, що має базуватися на підзаконній регламентаціі, водночас інші сфери мають базуватися на регламентації законодавчій.

3. Можна запропонувати вузьке тлумачення механізму реалізації повноваження щодо визначення засад внутрішньої і зовнішньої політики. Нагадаємо, що 1 липня 2010 р. Верховна Рада України ухвалила Закон «Про засади внутрішньої і зовнішньої політики» № 2411-VI. Можна припустити, що визначення засад внутрішньої і зовнішньої політики реалізоване шляхом ухвалення спеціального закону, інші ж закони, ухвалені Верховною Радою України, охоплюються компетенцією парламенту щодо ухвалення законів (п. 1 ч. 1 ст. 85). Тому на часі формулювання актуального погляду КСУ на таке повноваження парламенту, як визначення засад внутрішньої і зовнішньої політики, з урахуванням усіх названих дискусійних питань і проблемних моментів. До того ж практика КСУ 2004 р. спростовує ідею виключно «засад» (принципи, начала) у регулюванні цін і тарифів.

У статті досліджено предмет законодавчого регулювання $i$ його межі в контексті нормативного регулювання цін (тарифи). Проаналізовано франиузький досвід конституційного регулювання $і$ практику Конституиійної Ради щодо предмета законодавчого регулювання. Висловлені пропозиції щодо вузької інтерпретації права парламенту стосовного визначення засад внутрішньої $і$ зовнішньӧ̈ політики 
шляхом ухвалення окремого закону про такі засади. Припускається, що визначення засад внутрішньої i зовнішньої політики реалізоване иляхом ухвалення Верховною Радою України спеціального Закону від 1 липня 2010 року № 2411-VI «Про засади внутрішньої $i$ зовнішньої політики», інші ж закони, ухвалені Верховною Радою України, охоплюються компетениією парламенту щодо ухвалення законів (пункт 1 частини 1 статmі 85). Зроблено висновок щодо невичерпності предмета законодавчого регулювання статтею 92 Конституиіi України. Зроблено висновок про те, що Уряд має право здійснювати саме індивідуальне правове регулювання у сфері тарифів, відповідний термін активно використовується в теорії права в контексті теоріi правового регулювання або механізму правового регулювання й означає здійснення правозастосування. Поіменування чотирьох сфер у пункті 3 статmі 106 Конституизі України (ціни, фінанси, інвестищї $i$ податки) означає єдиний підхід щодо них. Навряд чи логічно вбачати цінову сферу в цьому переліку як якусь особливу, що має особливий статус з погляду ї нормативного регулювання, таку, що має базуватися на підзаконній ретламентації, водночас інші сфери мають базуватися на ретламентації законодавчій. Крім того, практика Конституційного Суду України 2004 року спростовуе ідею виключно «засад» (принципи, начала) у регулюванні иін $i$ тарифів (рішення Конституційного Суду України від 16 березня 2004 року № 6-рn/2004 (справа про друковані періодичні видання), а також рішення від 15 квітня 2004 року № 10-pn/2004 (справа про визначення мінімальної ціни на иукор).

Ключові слова: предмет закону, компетенція парламенту, правотворчі повноваження уряду, ціни (тарифи).
Berchenko

H.

Subject of legislative regulation and its limits in the context of regulatory regulation of prices (tariffs)

The article examines the subject of legislative regulation and its limits in the context of regulatory regulation of prices (tariffs). The French experience of constitutional regulation and the practice of the Constitutional Council on the subject of legislative regulation are analyzed. Proposals have been made for a narrow interpretation of the parliament's right to determine the principles of domestic and foreign policy by adopting a separate law on such principles. It is assumed that the definition of the principles of domestic and foreign policy is implemented through the adoption of a special Law of Ukraine of July 1, 2010 Verkhouna Rada of Ukraine "On Principles of Domestic and Foreign Policy" № 2411-VI, other laws adopted by the Verkhouna Rada of Ukraine laws (paragraph 1 of part 1 of Article 85). The conclusion on inexhaustibility of a subject of legislative regulation by article 92 of the Constitution of Ukraine is made. It is concluded that the Government has the right to exercise individual legal regulation in the field of tariffs, the relevant term is actively used in legal theory in the context of legal regulation or legal regulation mechanism and means the implementation of law enforcement. Naming of four spheres in item 3 of Article 106 of the Constitution of Ukraine (prices, finances, investments and taxes) means a single approach to them. It is hardly logical to see the price sphere in this list as a special one that has a special status from the point of view of its normative regulation, one that should be based on by-laws, while other spheres should be based on legislative regulations. In addition, the Practice of the CCU of 2004 refutes the idea of exclusively "principles" (principles, principles) in the regulation of prices and tariffs (the decision of the CCU of March 16, 


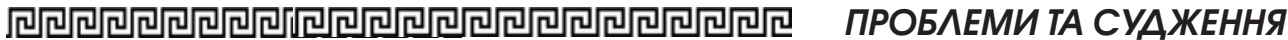

2004 № 6-rp/2004) (the case of printed periodicals) and the decision of 15 April 2004 № 10-rp/2004 (case on determining the minimum price for sugar).

Key words: subject of law, competence of parliament, law-making powers of government, prices (tariffs).

\section{Література}

1. Дутка Г.Я. Предмет закону Право України. 2001. № 4. С. 98-101.

2. Шайо А. Самоограничение власти: краткий курс конституционализма. Москва: Юристъ, 2001. 292 с.

3. Жакке Ж.-П. Конституциионное право и политические институты. Москва: Юристь, 2002. 365 с.

4. Тихомиров Ю.А. Конституциия, закон, подзаконный акт. Москва: Юрид. лuт., 1994. 136 c.
5. Совгиря О.В. Конституиійно-правовий статус Кабінету Міністрів України. Київ : Юрінком-Інтер, 2012. 464 с.

6. Гессен В.М. Основы конституционного права. Москва : РОССПЭН, 2010. $496 \mathrm{c}$.

7. Сарторі Дж. Порівняльна конституизійа інженерія : дослідження структур, мотивів, результатів. Київ : АртЕк, 2001. 211 с

8. Венеціанська комісія. Висновок щодо проекту Конституиії України від 21 травня 1996 р. № CDL-INF (96) 6 щодо тексту, затве рдженого $\mathrm{Koн}-$ ституційною комісією 11 березня 1996 р. Конституція незалежної України. Киї : Українська правнича фундація, 1997. Кн. 2. Ч. 1. С. 245-268.

9. Задихайло Д.Д. Кабінет Міністрів України як суб'єкт економічної системи : конституційно-правові засади. Харків : Юраŭm, 2013. 192 c. 